\title{
Changes in specific airways conductance and forced expiratory volume in one second after a bronchodilator in normal subjects and patients with airways obstruction
}

\author{
C. SKIN NER a n d K. N. V. PAL MER \\ Department of Medicine, University of Aberdeen
}

\begin{abstract}
Skinner, C. and Palmer, K. N. V. (1974). Thorax, 29, 574-577. Changes in specific airways conductance and forced expiratory volume in one second after a bronchodilator in normal subjects and patients with airways obstruction. Specific conductance (SGaw) and the forced expiratory volume in one second $\left(\mathrm{FEV}_{1}\right)$ were measured in 10 normal, 10 asthmatic, and 10 obstructive bronchitic subjects before and after aerosol salbutamol. Mean SGaw increased by $37 \%$ in normals, by $109 \%$ in asthmatics, and by $38 \%$ in

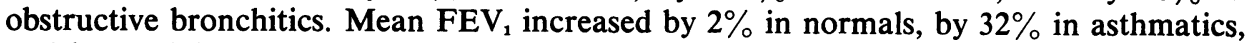
and by $12 \%$ in obstructive bronchitics. SGaw appears to be a more sensitive indicator than $\mathrm{FEV}_{1}$ of changes in airways calibre following a bronchodilator drug in normal subjects, but $\mathrm{FEV}_{1}$ is as good an indicator of these changes as SGaw in patients with airways obstruction.
\end{abstract}

The effect of bronchodilator drugs on diffuse airways obstruction is commonly assessed by measuring changes in the forced expiratory volume in one second $\left(\mathrm{FEV}_{1}\right)$. However, bronchial calibre is only one of several factors which determine the $\mathrm{FEV}_{1}$ (Pride, 1971) so that this test reflects only indirectly the resistance of the intrapulmonary airways. It has been claimed that direct measurement of airways resistance during quiet breathing or panting in a body plethysmograph is a more sensitive test of changes in airway calibre and, therefore, that in the assessment of the response to bronchodilator drugs, this measurement is preferable to the FEV $_{1}$ (Lloyd and Wright, 1963; Feinsilver, 1966; Cohen, 1969).

The aim of the present study is to compare changes in $\mathrm{FEV}_{1}$ and in the direct measurement of airways resistance following administration $\frac{0}{9}$ salbutamol by pressurized aerosol in norma毒 asthmatic, and chronic obstructive bronchitic subjects.

\section{PATIENTS AND METHODS}

Ten normal, 10 asthmatic, and 10 obstructi妾 bronchitic subjects were studied. The details afe given in Table I. The normal subjects were a non-smokers, free from respiratory disease, and the mean $\mathrm{FEV}_{1}$ and specific airways conductance (SGaw) were within the normal range. The asthmatic subjects were also non-smokers and had blood and/or sputum eosinophilia, and six had positive skin tests to several common alle? gens; the $\mathrm{FEV}_{1}$ and $\mathrm{SGaw}$ were both reduced

T A B L E I

DETAILS OF SUBJECTS STUDIED

\begin{tabular}{|c|c|c|c|c|c|}
\hline & No. & Sex & $\underset{(y r)}{\text { Mean Age }}$ & $\begin{array}{l}\text { Mean FEV } \\
\text { (1. ATPS) }\end{array}$ & $\begin{array}{c}\text { Mean SGaw } \\
\left(\mathrm{ml} / \mathrm{sec} / \mathrm{cmH}_{2} \mathrm{O} / 1 .\right)^{1}\end{array}$ \\
\hline $\begin{array}{l}\text { Normal } \\
\text { Asthmatic } \\
\text { Bronchitic }\end{array}$ & $\begin{array}{l}10 \\
10 \\
10\end{array}$ & $\begin{array}{r}\mathbf{M} \\
7 \mathbf{M} \\
\mathbf{3 F} \\
\mathbf{M}\end{array}$ & $\begin{array}{l}24 \\
34 \\
62\end{array}$ & $\begin{array}{l}4.43 \\
1.35 \\
0.84\end{array}$ & $\begin{array}{r}189 \\
33 \\
29\end{array}$ \\
\hline
\end{tabular}

${ }^{1}$ Normal range for SGaw $114-414 \mathrm{ml} / \mathrm{sec} / \mathrm{cmH}_{2} \mathrm{O} / \mathrm{l}$. 
the time of the study. The obstructive bronchitics were all heavy cigarette smokers, or had formerly been heavy cigarette smokers, none had positive skin tests and none had blood or sputum eosinophilia. In these subjects also, the mean $\mathrm{FEV}_{1}$ and SGaw were reduced.

Forced expiratory spirograms were obtained with a dry-wedge spirometer and from the best of three attempts the FEV $_{1}$ was recorded in litres (ambient temperature pressure saturated [APTS]). Airway resistance (Raw) and thoracic gas volume (TGV) were measured simultaneously in a constant-volume body plethysmograph at low flow rates. The result was expressed as specific airways conductance, which is the reciprocal of airways resistance per litre of thoracic gas volume (1/Raw $\times$ TGV). This measurement takes account of the fact that bronchial calibre and hence airways resistance varies with lung volume. Each reading was the mean of three determinations, and statistical analysis was performed on the logarithms of the SGaw values since the distribution of SGaw is lognormal or skewed (Guyatt and Alpers, 1968).

The measurements were made at the same time of the day, before and 10 minutes after the inhalation of $200 \mu \mathrm{g}$ of salbutamol from a pressurized aerosol. The changes in $F_{1}$ and SGaw after salbutamol in the normal subjects are shown in Table II. In six there was a small increase in $\mathrm{FEV}_{1}$, ranging from $50 \mathrm{ml}$ to $250 \mathrm{ml}$, while in four there was no change. The mean increase was only $90 \mathrm{ml}$, which is $2 \%$ of the mean baseline value, but this small increase is significant $(P<0.02)$. In the same subjects an increase in SGaw ranging from 10 to $74 \%$ of the baseline value was seen. The mean increase in SGaw was $37 \%$ of the mean baseline value $(P<0.001)$.

In the asthmatics (Table III) there was a substantial rise in $\mathrm{FEV}_{1}$ in all patients after

T A B L E I I

CHANGES IN FEV $_{1}$ AND SGaw AFTER SALBUTAMOL IN NORMAL SUBJECTS

\begin{tabular}{|c|c|c|c|c|c|c|c|c|}
\hline \multirow[b]{3}{*}{ Subject } & \multicolumn{4}{|c|}{$\begin{array}{l}\text { FEV }_{1} \\
\text { (1. ATPS) }\end{array}$} & \multicolumn{4}{|c|}{$\underset{\left(\mathrm{ml} / \mathrm{sec} / \mathrm{cmH}_{2} \mathrm{O} / \mathrm{l} .\right)}{\text { SGaw }}$} \\
\hline & \multicolumn{2}{|c|}{ Salbutamol } & \multicolumn{2}{|c|}{ Change } & \multicolumn{2}{|c|}{ Salbutamol } & \multicolumn{2}{|c|}{ Change } \\
\hline & Before & After & Litres & $\%$ & Before & After & $\begin{array}{c}(\mathrm{ml} / \mathrm{sec} / \\
\mathrm{cmH}, \mathrm{O} / \mathrm{l} .)\end{array}$ & $\%$ \\
\hline $\begin{array}{r}1 \\
2 \\
3 \\
4 \\
5 \\
6 \\
7 \\
8 \\
9 \\
10\end{array}$ & $\begin{array}{l}4.15 \\
4.40 \\
3.75 \\
4.90 \\
4.90 \\
4.45 \\
3.70 \\
5.10 \\
4.60 \\
4.35\end{array}$ & $\begin{array}{l}4.30 \\
4.40 \\
4.00 \\
5.05 \\
4.95 \\
4.55 \\
3.85 \\
5.10 \\
4.60 \\
4.35\end{array}$ & $\begin{array}{l}+0.15 \\
0 \\
+0.25 \\
+0.15 \\
+0.05 \\
+0.10 \\
+0.15 \\
0 \\
0 \\
0\end{array}$ & $\begin{array}{r}+4 \\
0 \\
+7 \\
+3 \\
+1 \\
+2 \\
+4 \\
+4 \\
0 \\
0\end{array}$ & $\begin{array}{l}172 \\
283 \\
178 \\
212 \\
242 \\
132 \\
153 \\
122 \\
208 \\
188\end{array}$ & $\begin{array}{l}274 \\
312 \\
309 \\
356 \\
338 \\
146 \\
210 \\
142 \\
302 \\
203\end{array}$ & $\begin{array}{l}+102 \\
+\quad 29 \\
+131 \\
+144 \\
+96 \\
+14 \\
+57 \\
+20 \\
+94 \\
+15\end{array}$ & $\begin{array}{r}+59 \\
+10 \\
+74 \\
+68 \\
+40 \\
+11 \\
+37 \\
+16 \\
+45 \\
+8\end{array}$ \\
\hline Mean & 4.43 & $4 \cdot 52$ & $+0.09^{1}$ & +2 & 189 & 259 & +70 & $+37^{2}$ \\
\hline
\end{tabular}

T A B L E I I I

CHANGES IN FEV 2 AND SGaw AFTER SALBUTAMOL IN ASTHMATICS

\begin{tabular}{|c|c|c|c|c|c|c|c|c|}
\hline \multirow[b]{3}{*}{ Patient } & \multicolumn{4}{|c|}{$\begin{array}{c}\text { FEV }_{1} \\
\text { (1. ATPS) }\end{array}$} & \multicolumn{4}{|c|}{$\begin{array}{c}\text { SGaw } \\
\left(\mathrm{ml} / \mathrm{sec} / \mathrm{cmH}_{3} \mathrm{O} / 1 .\right)\end{array}$} \\
\hline & \multicolumn{2}{|c|}{ Salbutamol } & \multicolumn{2}{|c|}{ Change } & \multicolumn{2}{|c|}{ Salbutamol } & \multicolumn{2}{|c|}{ Change } \\
\hline & Before & After & Litres & $\%$ & Before & After & $\begin{array}{c}\mathrm{ml} / \mathrm{sec} / \\
\mathrm{cmH} / \mathrm{O} / \mathrm{l}\end{array}$ & $\%$ \\
\hline $\begin{array}{r}1 \\
2 \\
3 \\
4 \\
5 \\
6 \\
7 \\
8 \\
9 \\
10\end{array}$ & $\begin{array}{l}0.75 \\
1.55 \\
2.40 \\
1.40 \\
1.45 \\
1.25 \\
1.55 \\
1.65 \\
0.70 \\
0.75\end{array}$ & $\begin{array}{l}1.15 \\
1.85 \\
2.85 \\
1.80 \\
2.00 \\
1.75 \\
1.95 \\
1.85 \\
1.35 \\
1.20\end{array}$ & $\begin{array}{r}+0.40 \\
+0.30 \\
+0.45 \\
+0.40 \\
+0.55 \\
+0.50 \\
+0.40 \\
+0.20 \\
+0.65 \\
+0.45\end{array}$ & $\begin{array}{r}+53 \\
+19 \\
+19 \\
+29 \\
+38 \\
+40 \\
+26 \\
+12 \\
+93 \\
+60\end{array}$ & $\begin{array}{r}8 \\
29 \\
35 \\
30 \\
26 \\
62 \\
29 \\
86 \\
5 \\
18\end{array}$ & $\begin{array}{r}24 \\
43 \\
66 \\
34 \\
91 \\
80 \\
85 \\
189 \\
26 \\
50\end{array}$ & $\begin{array}{l}+16 \\
+14 \\
+31 \\
+\quad 4 \\
+65 \\
+18 \\
+56 \\
+103 \\
+21 \\
+32\end{array}$ & $\begin{array}{r}+200 \\
+48 \\
+89 \\
+13 \\
+250 \\
+29 \\
+193 \\
+120 \\
+420 \\
+178\end{array}$ \\
\hline Mean & $1 \cdot 35$ & $1 \cdot 78$ & +0.43 & $+32^{1}$ & 33 & 69 & +36 & $+109^{1}$ \\
\hline
\end{tabular}


T A B L E I V

CHANGES IN FEV 1 AND SGaw AFTER SALBUTAMOL IN BRONCHITICS

\begin{tabular}{|c|c|c|c|c|c|c|c|c|}
\hline \multirow[b]{3}{*}{ Patient } & \multicolumn{4}{|c|}{$\begin{array}{l}\text { FEV }_{1} \\
\text { (1. ATPS) }\end{array}$} & \multicolumn{4}{|c|}{$\underset{\left(\mathrm{ml} / \mathrm{sec} / \mathrm{cmH}_{2} \mathrm{O} / 1 .\right)}{\text { SGaw }}$} \\
\hline & \multicolumn{2}{|c|}{ Salbutamol } & \multicolumn{2}{|c|}{ Change } & \multicolumn{2}{|c|}{ Salbutamol } & \multicolumn{2}{|c|}{ Change } \\
\hline & Before & After & Litres & $\%$ & Before & After & $\begin{array}{c}\mathrm{ml} / \mathrm{sec} / \\
\mathrm{cmH}_{2} \mathrm{O} / \mathrm{l}\end{array}$ & $\%$ \\
\hline $\begin{array}{r}1 \\
2 \\
3 \\
4 \\
5 \\
6 \\
7 \\
8 \\
9 \\
10 \\
\end{array}$ & $\begin{array}{l}1.00 \\
0.35 \\
1.15 \\
0.90 \\
0.55 \\
1.15 \\
1.15 \\
0.75 \\
0.40 \\
1.00 \\
\end{array}$ & $\begin{array}{l}0.90 \\
0.45 \\
1.25 \\
1.05 \\
0.70 \\
1.35 \\
1.25 \\
0.85 \\
0.55 \\
1.05\end{array}$ & $\begin{array}{l}-0.10 \\
+0.10 \\
+0.10 \\
+0.15 \\
+0.15 \\
+0.20 \\
+0.10 \\
+0.10 \\
+0.15 \\
+0.05\end{array}$ & $\begin{array}{r}-10 \\
+29 \\
+9 \\
+17 \\
+27 \\
+17 \\
+99 \\
+13 \\
+38 \\
0\end{array}$ & $\begin{array}{r}35 \\
17 \\
38 \\
65 \\
14 \\
21 \\
42 \\
24 \\
8 \\
24\end{array}$ & $\begin{array}{r}34 \\
25 \\
53 \\
108 \\
17 \\
28 \\
51 \\
29 \\
16 \\
35\end{array}$ & $\begin{array}{l}-1 \\
+8 \\
+15 \\
+43 \\
+3 \\
+7 \\
+9 \\
+5 \\
+8 \\
+11\end{array}$ & $\begin{array}{r}+3 \\
+\quad 47 \\
+\quad 39 \\
+\quad 66 \\
+21 \\
+33 \\
+\quad 21 \\
+21 \\
+100 \\
+\quad 46\end{array}$ \\
\hline Mean & 0.84 & 0.94 & $+0 \cdot 10$ & $+12^{1}$ & 29 & 40 & +11 & $+38^{2}$ \\
\hline
\end{tabular}

${ }^{1} \mathrm{P}<0.01$.

${ }^{2} \mathbf{P}<0.001$.

salbutamol. The mean increase was $430 \mathrm{ml}$, which is $32 \%$ above the mean baseline value $(\mathrm{P}<0.001)$. The mean increase in SGaw after salbutamol was $109 \%$ of the mean baseline value $(P<0.001)$. In the bronchitics (Table IV), nine showed a small increase in $\mathrm{FEV}_{1}$ after salbutamol, and in one patient there was a slight fall. The mean increase in $\mathrm{FEV}_{1}$ was $100 \mathrm{ml}$, which was similar to that seen in the normal subjects. However, since the mean pre-salbutamol $\mathrm{FEV}_{1}$ value was much lower in the bronchitics than in the normal subjects, this mean increase of $100 \mathrm{ml}$ represents a larger percentage change of $12 \%(P<0.01)$. The mean increase in SGaw, on the other hand, was less than that seen in normal subjects, although the percentage change $(38 \%)$ was essentially the same $(\mathbf{P}<0.001)$.

\section{DISCUSSION}

In the normal subjects, the bronchodilator effect of salbutamol is clearly shown by the substantial rise in SGaw. By comparison, the mean increase in $\mathrm{FEV}_{1}$, although statistically significant, was small, and this was also the case for the $\mathrm{FEV}_{0.5}$ and $\mathrm{FEV}_{0.75}$. A similar disparity between the increase in FEV $_{1}$ and SGaw following bronchodilator drugs in normals has been reported by McFadden, Newton-Howes, and Pride (1970) and by Bouhuys and van de Woestijne (1971). The former workers thought that this was largely due to their finding that the elastic recoil pressure of the lung, and hence the effective driving force for maximal expiratory air flow, was temporarily reduced after the bronchodilator. However, they used doses of isoprenaline much in excess of those commonly given therapeutically and suggested that a similar reduction in elastic recoil pressure might not be found with more conventional doses Bouhuys and van de Woestijne (1971) used smaller doses of the same drug. They found no change in elastic recoil pressure and proposed $\mathrm{a}^{\oplus}$ simpler explanation for the disparity between the two methods in detecting changes in airways calibre. They suggested that reduction in bronchias smooth muscle tone due to the drug leads not onlso to increased airways calibre, but also to increased airways collapsibility on expiration. Increased airways calibre results in increased specific con $\frac{O}{3}$ ductance, but increased collapsibility limits the increase in air flow during forced expiration anफ़ so limits the rise in $\mathrm{FEV}_{1}$ which might be expected to result from the increase in bronchial calibre.

If the hypothesis of Bouhuys and van de Woestijne (1971) be accepted, the large increases in both SGaw and FEV 1 after salbutamol in our asthmatics reflect the substantial degree of bronchodilatation which is only partially offset by increased airways collapsibility. In the bronchitics? on the other hand, while the increase in $\mathrm{FEV}_{D}$ was proportionately greater than in normals, the mean increase in SGaw was no greater than that seen in normals. This last finding differs from that of Astin (1972), who showed a greater increase in SGaw in bronchitics than in normals afterw inhalation of isoprenaline. He used a much large dose of bronchodilator than we did $-6 \mathrm{mg}$ ofo isoprenaline compared with $200 \mu \mathrm{g}$ of salbutamo厉 used in this study-and this difference in dosage? may well account for the effect he observed.

The results of this study suggest that in norma subjects SGaw is more sensitive than FEV $_{1}$ in detecting the effects of a bronchodilator drug or $\vec{B}$ bronchial calibre. However, in patients with airo ways obstruction the more easily measure 
$\mathrm{FEV}_{1}$ is as good an indicator of changes in airway calibre following bronchodilators as the SGaw. This latter measurement requires much more expensive equipment than is needed for the FEV $_{1}$.

We thank Professor David Kerridge for statistical advice.

\section{REFERENCES}

Astin, T. W. (1972). Reversibility of airways obstruction in chronic bronchitis. Clinical Science, 42, 725.

Bouhuys, A. and van de Woestijne, K. P. (1971). Mechanical consequences of airway smooth muscle relaxation. Journal of Applied Physiology, 30, 670 .

Cohen, B. M. (1969). Airways flow resistance as a measure of the efficiency of inhalants in clinical drug trials. Helvetica Medica Acta, 34, 455.
Feinsilver, O. (1966). Airway resistance as an index of effectiveness of bronchodilating drugs. Journal of Allergy, 38, 195.

Guyatt, A. R. and Alpers, J. H. (1968). Factors affecting airways conductance: a study of $\mathbf{7 5 2}$ working men. Journal of Applied Physiology, 24, 310 .

Lloyd, T. C. and Wright, G. W. (1963). Evaluation of methods used in detecting changes of airway resistance in man. American Review of Respiratory Diseases, 87, 529.

McFadden, E. R., Newton-Howes, J., and Pride, N. B. (1970). Acute effects of inhaled isoproterenol on the mechanical characteristics of the lungs in normal man. Journal of Clinical Investigation, 49, 779.

Pride, N. B. (1971). The assessment of airflow obstruction: role of measurements of airways resistance and of tests of forced expiration. British Journal of Diseases of the Chest, 65, 135.

Requests for reprints to: Dr. K. N. V. Palmer. University Department of Medicine, Foresterhill, Aberdeen AB9 2ZD. 